\title{
Aspects of assessing the quality of education at a university
}

\author{
Victor Antoshkin ${ }^{1 *}$, Irma Levina ${ }^{2}$, Ivan Sergiyenko ${ }^{3}$, Rashit Tagariyev $^{4}$, and Dina \\ Fatkhulova $^{2}$ \\ ${ }^{1}$ Bashkir State Pedagogical University named after M. Akmulla, Department of Philosophy, \\ Sociology and Political Science, Research Institute of Education Development Strategy, Ufa, Russia \\ ${ }^{2}$ Bashkir State Pedagogical University named after M. Akmulla, Research Institute of Education \\ Development Strategy, Ufa, Russia \\ ${ }^{3}$ Bashkir State Pedagogical University named after M. Akmulla, Department of Pedagogy and \\ Psychology of Professional Education, Research Institute of Education Development Strategy, Ufa, \\ Russia \\ ${ }^{4}$ Birsk branch of Bashkir State University, Department of Technological Education, Doctor of \\ Pedagogical Sciences, Birsk, Russia
}

\begin{abstract}
The present research is aimed at identifying the quality of education from the perspective of students' vision as participants in this educational process (according to the following criteria: fundamentality, sufficiency, modernity, level of digitalization of the quality of education), its impact on their educational level, and the study of students' motivation to learn, based on their assessment of the content level of educational curricula. The main research method is a comparative sociological study, which compares the research data of students of the M. Akmulla Bashkir State Pedagogical University (BSPU) with the results of other monitoring studies conducted in the Russian Federation and the Republic of Bashkortostan. In addition to the questionnaire method, the focus group method was also used. The study revealed students' attitudes to the quality of education, motivation to study, assessment of the content and quality of education, attitude to technologies, and learning conditions. According to the results of the 2019 study, $75 \%$ of students of BSPU were generally satisfied with the level of education quality. The novelty of the research is based on the following facts: quantitative parameters dominate over qualitative ones, which, as a result, leads to the information overload of the educational process subjects and a decrease in the level of competencies that determine the ability of students to think independently and analyze information.
\end{abstract}

Keywords: quality of education, sociological research, the content of education, innovative technologies.

\section{Introduction}

In this article, the term of quality of education is revealed from the sociological standpoint, whose essence is determining the state and result of the education process in society from

*Corresponding author: vicant21@gmail.com 
the perspectives of the needs and expectations of various socio-professional groups. The quality of education is determined not only through assessment of general indicators but it also involves aspects, such as levels of educational content, efficiency and effectiveness of the applied forms and methods of training, human resources potential, and other factors that determine professional and competence level of students. To correctly assess the quality of education, it is necessary to analyze two of its components: to assess the quality of knowledge received by students and the activity component of an educational institution at the municipal, regional, and federal levels [1, p. 4]. The quality of education is a measure of identifying the correspondence of the level of education and the level of training obtained by a specialist with both his expectations and expectations of the consumer [2, p. 78].

The research goal is to identify the specifics of students' attitude to the quality of education acquired (its fundamentality, sufficiency, and modernity), as well as to study the motivation for higher education, and the respondents' assessment of the content of educational programs.

Research objectives aim at revealing the content of the concept of quality of education as a sociological category; identifying students' ideas concerning the quality of education; analyzing motivation for learning; investigating the relationship between the content of education and respondents' assessment of the quality of education; revealing students' attitude to technologies and learning conditions; as well as showing the relationship between research activities of students and the quality of their education.

The research hypothesis is formulated as follows: the quality of education is a systembased formation that depends on the following set of factors: educational technologies, educational activity conditions, motivation to obtain higher education, the content of the educational program, list of academic subjects, professional qualification level of teachers, the possibility of free choice of disciplines, teachers and textbooks, professional inclinations and vocation, and the cognitive activity of students.

\section{Methods}

This study was conducted in March-April of 2019 at the BSPU. The respondents were university students. A two-stage sample was used in the sociological study, combining elements of probabilistic and targeted sampling. The focus of the study at the first stage was to select students of all five years of study from 11 faculties. This made it possible to ensure the selection of typical representatives of the general population. At the second stage, study groups of students of a particular faculty were randomly selected, where a continuous study was conducted to ensure the principle of equal probability of any of the respondents being included in the sample. The total number of respondents was 344 students.

The total sample size was as follows: first-year students $-25 \%$, second-year students $20 \%$, third -year students $-24 \%$, fourth-year students $-22 \%$, and fifth-year students $-9 \%$. The study covered both undergraduate and specialty students. At the stage of the pilot study, the focus group method was used, as well as the method of comparative sociological research.

\section{Results and discussion}

Students' satisfaction with the quality of education is shown in Table 1 and Figure 1.

As can be seen from Table 1, approximately three-quarters of BSPU students were generally satisfied with the quality of education. About $25 \%$ of the students were not satisfied. In the current education system, it is important to find out one of the main components, namely, the ability of students to choose academic disciplines and courses. 
Table 1. Students' satisfaction with the quality of education.

\begin{tabular}{|c|c|}
\hline Answer option & Number of respondents (\%) \\
\hline Yes & 27 \\
\hline Rather yes & 50 \\
\hline Probably not & 16 \\
\hline No & 6 \\
\hline
\end{tabular}

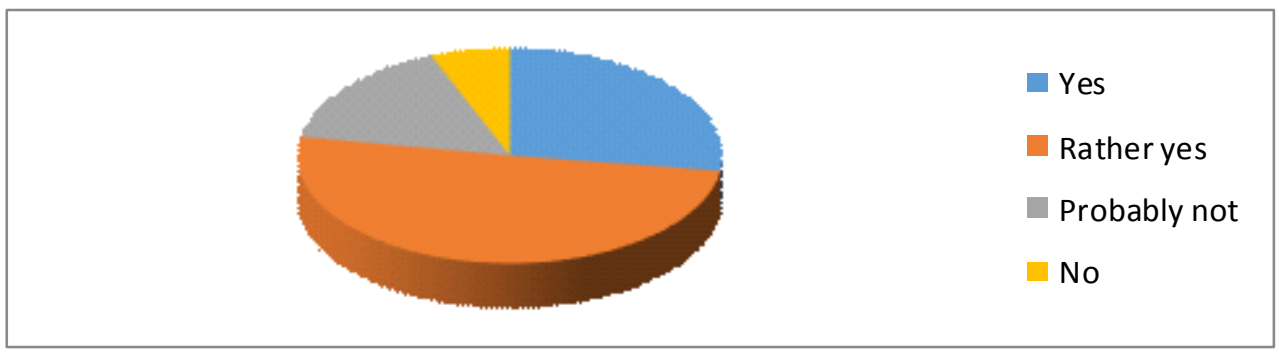

Fig. 1. Students' satisfaction with the quality of education.

The results of the sociological survey on the possibility of free choice of disciplines and courses are presented in Table 2 and Figure 2.

Table 2. Does the faculty provide a procedure for the free choice of disciplines and courses?

\begin{tabular}{|c|c|}
\hline Answer option & Number of respondents (\%) \\
\hline Yes & 41 \\
\hline No & 28 \\
\hline Do not know & 31 \\
\hline
\end{tabular}

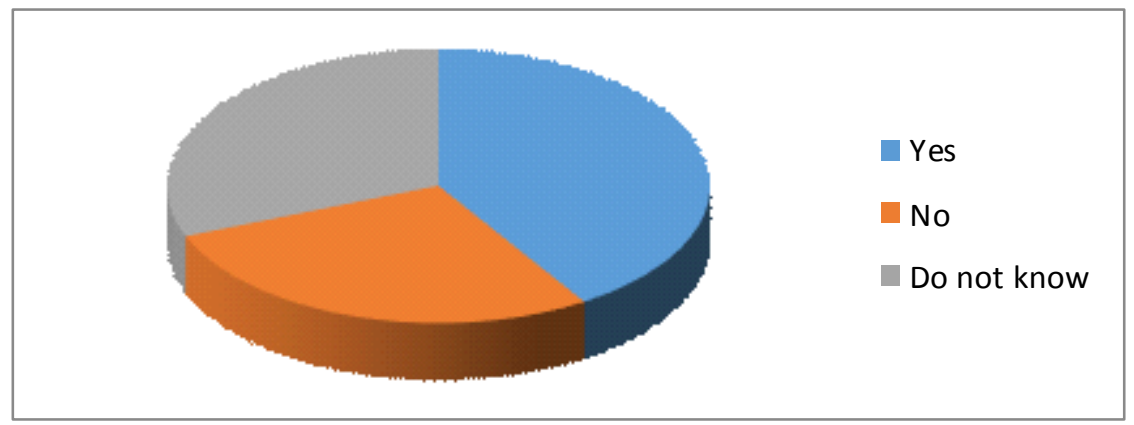

Fig. 2. Does the faculty provide a procedure for the free choice of disciplines and courses?

About two-thirds of the BSPU students believe that the procedure of free choice is available at their faculty. In fact, the situation is different, which was revealed as a result of research based on the focus group method, used involving students of three faculties. First, it was revealed that the possibility of selecting certain disciplines was unknown to a significant part of students. Second, the existing choice of disciplines in practice was often formal. Third, in practice, elective subjects were suggested by the heads of general education programs rather than by the students themselves. Fourth, some students chose certain disciplines on the advice of the Dean's office or teachers, to pass exams more easily. It should be assumed that the procedures for free choice in Russian universities, in the form provided for by the Bologna Convention, are poorly implemented in practice. 
The following research results have shown that only $27 \%$ of students fully supported the use of electronic technologies and resources in the educational process. Another $39 \%$ of students approved their use as an additional information resource and technology in the learning process. At that, students pointed to the phenomenon of information overload associated with working with electronic resources, while $11 \%$ of respondents noted a decrease in the quality of training. Previously conducted sociological studies of students in the Republic of Bashkortostan (2015-2018) have shown similar attitudes of students to electronic resources and distance learning technologies.

The following answers were received to the question concerning the preferred teaching methods and techniques:

- $91 \%$ of respondents preferred live discussion-based forms of learning, providing the most complete understanding of the essence of the subject matter under consideration;

- training through the use of the Internet, computer, and remote forms of work was approved by only $9 \%$ of respondents; at the same time, only one-fifth of students expressed satisfaction with the quality of the Internet capabilities and the operating system of computer equipment.

The same conclusions were drawn by researchers of the Institute for Social Analysis and Prediction (ISAP) of the Russian Presidential Academy of National Economy and Public Administration (RANEPA), who surveyed 12,201 students and 4,000 teachers from 53 branches. The results have shown that the majority of respondents believed that the quality of education had significantly decreased due to the implementation of distance learning, which turned out to be less effective than the traditional full-time form. At that, $69.9 \%$ of students and $85.5 \%$ of teachers noted a full-time education as preferred [3]. A joint study by the National Research University Higher School of Economics and Tomsk State University, which surveyed 35,000 students from 400 universities in Russia from March to June 2020, also noted that more than half of the students surveyed (65\%) believed that distance learning was less effective than in-person learning. Consequently, the technocratic illusions that computer technology will solve all the problems of contemporary education have not been justified. The formal and technical aspect of education does not negate but rather increases the importance of the content aspect of education.

Continuing the research, it should be noted that all-Russian sociological studies show that the quality of education is determined by the priority social characteristics, namely, the attitude of teachers to their work and the vocation to the basic procedural content of the work performed [4-11]. “...On average, 75\% of teachers feel psychological comfort associated with their work, because it corresponds to their professional vocation. The remaining $25 \%$ of teachers feel cool about their work, experience psychological discomfort, which significantly affects the quality of work and the overall quality of education" $[12, p$. 58]. Hence, the presence of professional inclinations and abilities in future teachers is a factor contributing to improving the quality of education.

\section{Conclusion}

According to the results of the study, the following conclusions have been drawn:

$-75 \%$ of BSPU students were generally satisfied with the level of quality of education.

- The orientation of students to work in the specialty after completing their studies in pedagogical universities is significantly lower than that of students of technical universities.

- Administration of higher education institutions and the teaching staff should be encouraged to pay special attention to the applied significance of the content of the subjects taught. Students can be greatly assisted by self-education skills, working with sources, meta-subject skills, and turning to theory in the course of practical activities. 
- A mechanism and a procedure for selecting subjects and training courses at the university should be developed and implemented.

- The necessary balance between theory and practice, lectures, and practical classes should be formed.

- A balance between science and education should be provided by increasing the share of free scientific activity in the total workload of teachers and students, as well as a mechanism for choosing innovative subjects and courses should be created.

\section{References}

1. T.A. Aymaletdinov, I.Ye. Kuznetsova, Monitoring of Public Opinion: Economic and Social Changes Journal (Public Opinion Monitoring), 5(117), 2-8 (2013)

2. D.A. Kalugina, Obrazovanie i Nauka, 6, 7-11 (2013)

3. N. Pomerantseva, Pochemu studenty i prepodavateli nevzlyubili distantsionnoye obucheniye [Why students and teachers disliked distance learning], Vedomosti, 28 May (2020). Accessed on: December 20, 2020. [Online]. Available: https://www.vedomosti.ru/management/articles/2020/05/28/831354-distantsionnoeobuchenie

4. V.N. Antoschkin, Eurasian Journal of Analytical Chemistry, 12(7b), 1-9 (2017)

5. M.V. Klimenskikh, O.S. Vindeker, A.S. Shcheka, N.A. Korepina, Ye.A. Golendukhina, Pedagogicheskoye obrazovaniye v Rossii, 10, 41-47 (2017)

6. O.V. Kuznetsova, International Journal of Applied and Fundamental Research, 8(2), 362-364 (2015)

7. I.R. Levina, Sotsial'nyy intellekt pedagoga-muzykanta [Social intelligence of a music teacher] (Bashkir State Pedagogical University named after M. Akmullah, Ufa, 2019)

8. V.S. Sobkin, O.V. Tkachenko, A.V. Fedyunina, Student pedagogicheskogo vuza: otnosheniye k obrazovaniyu i professional'nyye plany [Student of a pedagogical university: attitude to education and professional plans] (Center for Sociology of Education, Russian Academy of Education, Moscow, 2003)

9. R. Singh, D. Hurley, Journal of Teaching and Learning with Technology, 6, 65-75 (2017)

10. D.R. Fatkhulova, G.R. Galiyeva, Modern pedagogical education, 9, 156-160 (2019)

11. V.N. Antoshkin, Sotsiologiya sel'skoy shkoly: opyt regional'nykh issledovaniy [Sociology of a rural school: the experience of regional studies] (Bashkir State Pedagogical University named after M. Akmullah, Ufa, 2017)

12. F.E. Sheregi, A.L. Arefyev, P.Ye. Tsarkov, Usloviya truda pedagogov: khronometricheskiy i sotsiologicheskiy analiz [Working conditions of teachers: chronometric and sociological analysis] (Centre for Sociological Research, Moscow, 2016) 